Instructions for authors, subscriptions and further details:

http://ijep.hipatiapress.com

\title{
Proactive and Reactive Aggressive Behavior in Bullying: The Role of Values
}

Natalia Jara, Jose A. Casas, Rosario Ortega-Ruiz ${ }^{1}$

1) Universidad de Córdoba

Date of publication: February $24^{\text {th }}, 2017$

Edition period: February 2017 - June 2017

To cite this article: Jara, N; Casas, J.A. \& Ortega-Ruiz, R. (2017).

Proactive and Reactive Aggressive Behavior in Bullying: The Role of Values. International Journal of Educational Psychology, 6(1), 1-24. doi: 10.17583/ijep.2017.2515

To link this article: http://dx.doi.org/10.17583/ijep.2017.2515

\section{PLEASE SCROLL DOWN FOR ARTICLE}

The terms and conditions of use are related to the Open Journal System and to Creative Commons Attribution License (CC-BY). 


\title{
Proactive and Reactive Aggressive Behavior in Bullying: The Role of Values
}

\author{
Natalia Jara \\ Jose A. Casas \\ Rosario Ortega-Ruiz \\ Universidad de Córdoba \\ Universidad de Córdoba \\ Universidad de Córdoba
}

\begin{abstract}
The study of violence and bullying in schools is a line of scientific research that has contributed significantly to knowledge on human aggressiveness, especially in children and adolescents. This article shows that there are two patterns of aggressive behavior: proactive and reactive. Both are present in bullying, as are other psychological aspects pertaining to the individuals involved, such as basic personality traits, self-esteem and values. This study links both proactive and reactive behavioral patterns to involvement and non-involvement in school bullying. The results reveal that basic personality traits, such as neuroticism, have a direct impact on proactive and reactive bullying, as do the social and individual dimensions of self-esteem and social and moral values. These findings confirm that variables relating to personal and social values are, in turn, related to proactive and reactive aggressive behavior in bullying for those involved and not involved in bullying. However, they also highlight that while aggressors engage in more proactive aggressive behavior, reactive aggression is more frequent among victims.
\end{abstract}

Keywords: Aggressive Behavior, Bullying, Personality Traits, Self-esteem and Values 


\section{Agresividad Proactiva y Reactiva en el Fenómeno Bullying: El Papel de los Valores}

Natalia Jara

Universidad de Córdoba
Jose A. Casas

Universidad de Córdoba
Rosario Ortega-Ruiz

Universidad de Córdoba

\section{Resumen}

La investigación sobre violencia escolar y bullying ha resultado ser una línea de de trabajo científico que ha contribuido de forma importante a los estudios sobre agresividad humana, especialmente en los años de la niñez y la adolescencia. El trabajo que este artículo presenta revela que la conducta agresiva en sus dos patrones básicos: conducta agresiva proactiva y conducta agresiva reactiva tienen presencia en el fenómeno bullying, así como otros aspectos de la psicología de los implicados (por ej. Aspectos básicos de personalidad, la autoestima, y los valores. Este estudio relaciona ambos patrones (reactivo y proactivo) con la implicación o no implicación en acoso escolar. Los resultados manifiestan que aspectos básicos de la personalidad, como el neuroticismo, inciden en la implicación en bullying tanto de forma proactiva como de forma reactiva, al igual que la autoestima y los valores sociomorales en sus dimensiones social e individual. Los resultados obtenidos en este trabajo confirman que las variables relativas a valores personales y sociales están relacionadas con la agresión reactiva y proactiva en bullying, tanto para la implicación como para la no implicación en el mismo, aunque se destacan como los agresores muestran una mayor presencia del patrón agresivo pro-activo y las víctimas, con una mayor presencia del patrón reactivo.

Palabras clave: Agresividad, acoso, rasgos de la personalidad, autoestima y valores. 
T nterpersonal violence. Labeling certain aggressive behaviors as "violence" is controversial within the field of scientific research. Regarded as an expression of aggressive attitudes and behaviors, violence carries social connotations that hinder the understanding of aggressiveness as a natural universal parameter (Pailing, Boon, \& Egan, 2014). However, violence cannot be assumed to be disconnected from the neurophysiological parameters which underlie all behavior. Violence is an expression of aggressive behavior that has lost many of its natural traits and incorporated others (Ortega, 2010). It often becomes a form of unjustified, immoral and cruel aggression, in which one individual exercises power over another. Aggressive behavior that occurs with a clear intention to harm, is not innate aggression but violence.

In studies on violence and bullying in schools, the concept is well defined. Bullying is a psychosocial phenomenon involving gratuitous, intentional aggression that takes advantage of an imbalance of power between the aggressor and the victim. It also has moral connotations from the perspective of both psychological and ethical-social dimensions, given that it is an immoral abuse of power and ethically reprehensible ( $\mathrm{Xu}$, Raine, Yu, \& Krieg, 2014).

Some authors consider that the concept of violence should be restricted to acts of physical aggression (Olweus, 1993). However, in line with the definition of the $\mathrm{WHO}$, an increasing number of researchers understand violence to include psychological, verbal and moral aggression. Ortega (2010) argued that violence is a form of aggressive behavior that comprises socio-moral elements which denote a breakdown in communication patterns and the mitigation of conflicts of interest via the usual channels of communication and dialogue. All violence includes, to some extent, the transgression of the norms of coexistence implicit in social regulation. Violence implies the use of force or power to dominate a situation in favor of the interests of the violent individual; however, it also requires the competent control of certain relational-type abilities, which is why moral injury is also considered violence (Pailing et al., 2014).

Some studies have concluded that violence is a long-term, stable construct expressed in different types of aggressive behavior throughout the life of a violent individual (Hart, Hofmann, Edelstein, \& Keller, 1997). This 


\section{Jara, Casas \& Ortega-Ruiz-Aggressive Behaviour}

leads us to question why some human beings fail to transform basic aggressive patterns of behavior into non-harmful verbal forms of communication in order to resolve conflicts of interest that arise in human relationships in a non-violent way. This suggests that it is necessary to go beyond the notion of the possible inheritability of aggressive behavior to inquire into the relationship between violence and personal and social moral criteria.

From a purely descriptive perspective, aggressive behavior can be proactive or reactive. There is no doubt that both predation and revenge can be grounds for violent acts. Some studies identify aggressive action as a response to an aggression received earlier. The figure of the aggressive victim or the victimized aggressor in bullying responds to the difficulty in clarifying the action-reaction interplay which is frequently implicit in aggressive actions that occur within relatively stable interpersonal relationships. As mentioned, certain aspects of interpersonal violence are related to social judgments, which underlie the intention or not to do harm (Bandura, 1973).

On occasion, it has been argued that there exists a spiral of violence, suggesting that the more aggressive acts an individual commits the more likely he or she is to engage in serious violent behavior in the future, with adolescence and early adulthood being the most vulnerable periods for this type of violence (Rutter, Giller, \& Hagell, 2000). Longitudinal studies have predicted that aggressive behavior exhibited in early childhood gives rise to a personality trait that can manifest itself in progressively more intense violent acts (Hart et al., 1997). It has been reported that the highest levels of violence occur during early adolescence (10 to 13 years old) and that violent behavior is also significant in later years (14-17 years old) (Pailing et al., 2014).

\section{Bullying in Adolescence: Aggressors and Victims}

Violence in schools comprises a wide range of aggressive or antisocial behavior such as disruptive acts, lack of respect for conventional discipline, absenteeism, vandalism and many more. Among these types of behavior, physical, verbal, psychological and relational aggression by one student or 
group of students against others who have fewer resources to defend themselves are the types of interpersonal violence that seem to be the most significant problem related to aggressive behavior in the school setting (Del Barrio, Martín, Almeida, \& Barrios, 2003). Although bullying is quite widespread throughout primary schooling, it does not appear to be as serious as it later becomes in adolescence.

The importance of adolescence as a stage of change and personality formation means that studies on violence and bullying in schools have become increasingly abundant and part of the approach to the psychology of aggressiveness. In this regard, some studies have highlighted that harassment among schoolchildren takes the form of role play in which a student assuming a dominant role, alone or in the company of others, intentionally, unjustifiably and protractedly attacks another student who assumes a submissive role inappropriate of the egalitarian social relationship that would morally correspond to them (Ortega, 2010). Given that this is a social phenomenon which is sustained over time and in which observers and other schoolchildren who support, reject or consent to what is happening inevitably become involved, the social problem becomes even more complex and poses knock-on negative effects in the school environment.

Victims of bullying do not display common personality traits, nor can it be said that they have a unique pattern of individual traits; in fact, no common risk factors have been found. However, in general, they frequently exhibit poor social skills and social adjustment. As such, many of them are unpopular and not highly regarded by others. A well-defined type is the socalled provocative victim, children who display controversial behavior and, although heavily involved in social networking, tend to fail socially. They draw attention to themselves by making social gaffes and are often used as scapegoats by their companions. Children who have been overprotected in their family environment and perhaps somewhat naïve are also, more often than not, victims of bullies. In addition, children who belong to different social groups are perceived as being weaker and those with a disability or requiring special educational needs are also victims of bullying (Zych, Ortega-Ruiz, \& Del Rey, 2015).

With regard to aggressors, leading studies conclude that they are usually physically and sometimes psychologically stronger than others, are 


\section{Jara, Casas \& Ortega-Ruiz-Aggressive Behaviour}

impulsive, have a low tolerance for frustration and find it difficult to obey rules and abide by norms. They engage in negative relationships with adults, often perform poorly at school and display a lack of self-criticism, yet are popular and highly regarded by their peers. Their social problems increase with age, but in the school years it is easy for them to be surrounded by fellow schoolmates, some of whom follow in their footsteps (Pellegrini, Bartini, \& Brooks, 1999; Salmivalli \& Nieminen, 2002). Bullying aggressors show a greater tendency to identify with the acknowledged dominionsubmission model (Ortega-Ruiz \& Mora-Merchán, 2008) by adopting the dominant role and demanding that their victim obey their command. They also find it more difficult to respond appropriately to the emotional state of others (affective empathy). However, they tend to express self-complacency with their actions and relationships, although they do not display a high level of self-esteem and self-awareness in their social efficacy. Moreover, although they are usually open to others, they avoid engaging in behavior that is susceptible of being branded as inappropriate by adults (Stoudt, 2006).

Personal variables relating to aggressive behavior include temperamental characteristics such as neuroticism, impulsivity and the compulsive search for new sensations (Caprara \& Pastorelli, 1993), as well as emotional variables, such as the aforementioned lack of empathy, inconsistency and the lack of a good hierarchical values system (Samper, Tur, Mestre, \& Cortés, 2008). With regard to the relationship between self-esteem and aggressive behavior, the studies are inconclusive. Some studies indicate a weak correlation between aggression and self-esteem (McCarthy \& Hoge, 1984), while others have found links between low self-esteem and a greater presence of threatening and aggressive behavior (Marsh, Parada, Yeung, \& Healey, 2001). Still others have found a positive relationship between low self-esteem and risk factors for antisocial and aggressive behavior. The personality of the aggressor is fundamentally proactive given that it is usually the aggressor who initiates an aggression. However, the complex process behind the social and temporal structure of bullying can also encompass reactive behaviors from victims who respond in the "wrong way" to provocation from an aggressor who displays a sustained strategy of 
intimidation and control; all of which makes it difficult to identify a single pattern (Dodge, 1997).

\section{Personal and Social Moral Values in Bullying}

In addition to the personality traits of its protagonists, the social context in which bullying occurs plays a significant role; particularly peer social networks and the immediate social environment, that is, the formal grouping structures established by the educational system in classrooms and during leisure and recreational activities supervised by teachers. Undeniably, bullying is related to opportunities for sociability and experiences with others (Poulin \& Boivin, 2000). For example, proactive aggressive adolescents tend to associate with proactive aggressive adolescents, but this does not appear to be the case when violence is reactive (Poulin \& Boivin, 1999). Perhaps this is based on the fact that children who exhibit reactive aggressive behaviors are negatively evaluated by their peer group, while proactive aggressors are socially valued for their often humoristic and leadership qualities (Dodge \& Coie, 1987).

As mentioned above, ethical values and criteria are compromised in bullying and may be different for proactive and reactive aggressors. Although there is little research on moral standards and bullying, the results of studies dealing with this issue are controversial. Some studies have found very few differences between the way aggressors and individuals not involved in bullying view the classroom (Cerezo, 2002). Salmivalli and Nieminen (2002) highlighted the importance of hierarchical personal values as well as the interaction of personal values and shared social values.

In this regard, the theory of moral disengagement (Bandura, 1999) has become a good paradigm for the study of values and social behavior. Bandura proposed the concept of moral disengagement to describe the cognitive process of evading critical input evidenced by the hierarchy of values in the face of the incongruity between what one thinks and what one does. Based on this theory, some studies have concluded that aggressors use more mechanisms of moral disengagement than victims (Ortega-Ruiz, Jiménez, \& Menesini, 2002). 


\section{Jara, Casas \& Ortega-Ruiz-Aggressive Behaviour}

\section{Proactive and Reactive Aggressive Behavior in Bullying}

Dodge (1997) analyzed the cognitive mechanisms that characterize aggression and identified two major patterns: proactive and reactive aggression. The distinction between proactive and reactive aggression has an important potential for supporting and clarifying ethological assumptions (Dodge \& Schwartz, 1997). Reactive aggression is based on the frustrationaggression model that occurs as a reaction to a threat and is often associated with intense emotions, high levels of impulsivity and hostility, and deficits in information processing (Raine et al., 2006) where the aggressor is frequently guided by the motivation to harm others without a specific objective.

An explanation for proactive aggression can be found in Bandura's (1973) social learning model as a strategy that intends to reach a goal, an objective or some kind of benefit through cold-blooded and instrumental behavior that involves harming others (Raine et al., 2006). Some studies have shown that the factors that lead to proactive aggression and the factors that lead to reactive aggression are interrelated, although it might be reasonable to assume that proactive and reactive aggression have different etiologies (Crick \& Dodge, 1996). It has also been demonstrated that both types of behavior are linked to different personality traits, styles of sociability, and especially each individual's personal and social values (Dodge \& Coie, 1987). In this respect, beliefs in social values regarding unjustified aggression, such as bullying, seem to be more closely associated with proactive rather than reactive aggression (Crick \& Dodge, 1996).

In this scientific context, our study has two main objectives. First, to observe the level of involvement in bullying in a sample of adolescents from Cordoba, Spain, with the aim of determining the proactive and reactive aggressive behavior patterns of those involved in bullying. And second, to define the relationship between proactive and reactive aggressive behavior patterns (Crick \& Dodge, 1996) of those involved and not involved in bullying, taking into account self-esteem as a slightly controversial measure of personality, as well as the social and individual dimensions of social and moral values. 


\section{Methodology}

\section{Participants}

A total of 326 students ( $\mathrm{n}=158 ; 48.5 \%$ female) from two secondary public schools, one in the capital city and the other in the province of Cordoba, participated in the study. The participants' age ranged from 12 to 18 years ( $\mathrm{M}=14.61 ; \mathrm{SD}=1.26$ for both sexes). The data was collected by means of convenience sampling, until completing the sample.

\section{Instruments}

The Big Five Inventory (BFI-10) (Rammstedt \& John, 2007), a questionnaire that comprises 10 items to measure the five major personality traits (extraversion, agreeableness, conscientiousness, neuroticism and openness to experience) was used. Examples of the items are: "I see myself as someone who is reserved" and "I see myself as someone who gets nervous easily". The responses are scored a 5-point Likert-type scale from "Strongly disagree" to "Strongly agree." The reliability of the scale is acceptable with levels of $\alpha=.83$ for the general questionnaire; $\alpha=.90$ for extraversion; $\alpha=.78$ for agreeableness; $\alpha=.84$ for conscientiousness; $\alpha=$ .88 for neuroticism, and $\alpha=.80$ for openness to experience (Rammstedt $\&$ John, 2007).

The validated version in Spanish of the European Bullying Intervention Project Questionnaire (EBIPQ) (Ortega-Ruiz, Del Rey, \& Casas, 2016) comprises 14 items with 5 Likert-type scale response options that measure the frequency of bullying behavior and range from "Never" to "More than once a week". The EBIQP consists of two scales. The aggression scale includes items such as "I have hit, kicked or pushed someone"; while the victimization scale includes items such as "Someone has hit, kicked or pushed me." The reliability levels are $\alpha=.82$ for the total number of subjects; $\alpha=.75$ for aggression, and $\alpha=.84$ of victimization. The questionnaire has been validated in six European countries (Spain, Poland, Italy, Germany, the United Kingdom and Greece) for use in different programs. 
The Rosenberg self-esteem scale (Pullmann \& Allik, 2000) is a 10-item Likert scale to measure self-esteem and self-acceptance. The items are answered on a 4 point scale from "Strongly Disagree" to "Strongly Agree". Examples of the items are "I am able to do things as well as most other people" or "On the whole, I am satisfied with myself". The RSES is the most widely used assessment tool to measure general self-esteem, which is understood as a general evaluation of an individual's worth as a human being (Pullmann \& Allik, 2000). The reliability level of the scale is $\alpha=.84$.

The values scale (Oliva, 2011) comprises 24 items to evaluate the importance that adolescent children give to a set of values involved in their positive development. The answers to the options range from 1 to 7 , with 1 being "Not important" and 7 "Most important" with items such as "Being admired by others." The scale measures three dimensions structured into: social values, personal values and individual values, whose levels of reliability are $\alpha=.87 ; \mathrm{a}=.82$, and $\alpha=.74$, respectively. The overall reliability of the scale is $\alpha=.88$.

The Reactive-Proactive Aggression Questionnaire (RPQ) designed by Raine et al. (2006) measures both types of aggressive behavior in adolescents. It consists of 23 items based on the proactive (instrumental) motivational dimension model such as "Had fights with others to prove who was on top", and in the reactive (hostility) dimension such as "Yelled when annoyed". A Likert scale is used to rate each item according to its frequency of occurrence from 0 to 2 where 0 is "Never", 1 is "Sometimes" and 2 is "Often." The reliability of the scale is $\alpha=.84$ for all items; $\alpha=.81$ for proactive aggression and $\alpha=.74$ for reactive aggression.

\section{Procedure}

The schools were contacted to invite them to participate in the study and permission was obtained to administer the questionnaires. The questionnaires were administered in groups with an approximate duration of 25-30 minutes. All participants were informed that the data would be confidential and anonymous. Participation was voluntary and also confidential. Data were gathered in accordance with the ethical standards and general principles of the American Psychological Association (APA). 


\section{Data Analysis}

A univariate descriptive analysis was performed for all the variables studied. In order to achieve the objectives proposed in the study, we first selected students involved and not involved in bullying in order to analyze the data separately. For the EBIPQ, a theoretical model was used in which the respondents who marked 2 ("Once or twice") or 1 ("Never") on the scale items were classified as not being involved in bullying, that is, these subjects denied any type of involvement according to the theoretical criteria on bullying involvement. We then analyzed the data of subjects who marked 3 ("Once or twice a month") or more on all the scale items. In order to obtain the percentages of aggressors and victims, those involved in bullying were analyzed using another theoretical model. According to this model, respondents who score 3 or more (i.e., once or twice a month or more) on items related to aggression or 2 or less on items related to victimization are aggressors. With victims the opposite occurs. Those who score 3 or more on the items related to victimization and 2 or less on the items related to aggression are considered victims. Respondents who score 3 or more on both scales correspond to the role of bully-victims.

We then performed an analysis using structural equation modeling. In the analysis, we used the maximum robustness estimation method due to the fact that the variables are of an ordinal nature and do not satisfy the assumption of normality. Furthermore, following the recommendations of $\mathrm{Hu}$ and Bentler (1999), we used a combination of several indices to contrast the appropriateness of the proposed models. The chi-square statistic in comparison to its degrees of freedom, the comparative fit index (CFI), the goodness of fit index (GFI), the Tucker-Lewis index (TLI), the root mean square error of approximation (RMSEA) and the root mean square residual (RMR) index were used. The standardized regression coefficients included in the model were estimated according to their level of significance. The data were analyzed using SPSS version 20 and EQS 6.1 statistical software. This software allows for polyclonal correlations, which are more suitable for variables of this type (Flora \& Curran, 2004). 
10 Jara, Casas \& Ortega-Ruiz-Aggressive Behaviour

\section{Results}

A univariate analysis was performed on all data in order to obtain the means and standard deviations of the variables (see Table 1). Following the theoretical criteria described above, the percentage of involvement in bullying was calculated by differentiating the three main roles: aggressors $(n$ $=45 ; 13.80 \%)$, victims $(n=54 ; 16.56 \%)$ and bully-victims $(n=12 ; 3.68 \%)$ (See Tables 2, 3 and 4).

Table 1.

Basic descriptions

\begin{tabular}{|c|c|c|c|c|c|c|c|c|}
\hline & $\mathrm{N}$ & Min I & Max & $M$ & SD & Variance & Skewness & Kurtosis \\
\hline Proactive Aggression & 326 & 1 & 3 & 1.31 & .321 & .103 & 1.439 .135 & 51.710 .270 \\
\hline Reactive Aggression & 326 & 1 & 3 & 1.81 & .345 & .119 & .378 .135 & $5 \quad .166 \quad .270$ \\
\hline Aggression Bullying & 326 & 1 & 5 & 1.75 & .653 & .427 & 1.587 .135 & 53.560 .269 \\
\hline Victimization Bullying & 326 & 1 & 5 & 1.89 & .761 & .579 & 1.327 .135 & 52.067 .269 \\
\hline Self-esteem & 326 & 1 & 3 & 2.38 & .271 & .073 & -.117 .135 & $5 \quad .757 \quad .269$ \\
\hline Extra & 326 & 1 & 5 & 3.54 & .935 & .874 & -.065 .135 & $5-.695 .269$ \\
\hline Agre & 326 & 2 & 5 & 3.51 & .806 & .649 & -.147 .135 & $5-.340 .269$ \\
\hline Consc & 326 & 1 & 5 & 3.23 & .919 & .844 & -.117 .135 & $5-.317 .269$ \\
\hline Neuroticism & 326 & 1 & 5 & 3.11 & .951 & .905 & -.170 & $5-.373 .269$ \\
\hline Openness & 326 & 1 & 5 & 3.56 & .888 & .789 & -.258 .135 & $5-.297 .269$ \\
\hline Social values & 326 & 1.67 & 7 & 4.74 & 1.186 & 1.407 & -.120 .135 & $5-.575 .269$ \\
\hline Personal values & 326 & 1.33 & 7 & 5.26 & 1.085 & 1.178 & -.920 .135 & $\begin{array}{lll}5.689 & .269\end{array}$ \\
\hline$\underline{\text { Individual values }}$ & 326 & .50 & 7 & 4.1 & 1.228 & 1.508 & $.060 \quad .135$ & $5-.623 .270$ \\
\hline
\end{tabular}


Table 2.

Aggressor profile

\begin{tabular}{lcccccccccc}
\hline & $\mathrm{N}$ & Min & Max & M & SD & \multicolumn{2}{c}{ Variance } & \multicolumn{2}{l}{ Skewness } & \multicolumn{2}{l}{ Kurtosis } \\
\hline Proactive Aggression & 45 & 1 & 3 & 1.40 & .379 & .144 & 1.181 & .354 & .813 & .695 \\
Reactive Aggression & 45 & 1 & 3 & 1.90 & .376 & .141 & .081 & .354 & .098 & .695 \\
Aggression Bullying & 45 & 1 & 5 & 2.18 & .812 & .660 & 1.891 & .354 & 3.636 & .695 \\
Victimization & 45 & 1 & 2 & 1.32 & .318 & .101 & 1.008 & .354 & -.007 & .695 \\
Bullying & 4 & & & & & & & & & \\
Self-esteem & 45 & 2 & 3 & 2.33 & .234 & .055 & .483 & .354 & -.002 & .695 \\
Extraversion & 45 & 2 & 5 & 3.90 & .975 & .950 & -.630 & .354 & -.280 & .695 \\
Agreeableness & 45 & 2 & 5 & 3.51 & .780 & .608 & .112 & .354 & -.638 & .695 \\
Conscientiousness & 45 & 1 & 5 & 3.02 & .994 & .988 & .063 & .354 & -.154 & .695 \\
Neuroticism & 45 & 1 & 5 & 3.13 & 1.115 & 1.243 & -.339 & .354 & -.539 & .695 \\
Openness & 45 & 2 & 5 & 3.53 & .944 & .891 & -.355 & .354 & -.386 & .695 \\
Social values & 45 & 1.89 & 6.78 & 4.3877 & 1.200 & 1.442 & -.103 & .354 & -.356 & .695 \\
Personal values & 45 & 1.78 & 6.56 & 5.2198 & 1.125 & 1.267 & -1.552 & .354 & 2.569 & .695 \\
Individual values & 45 & 2.67 & 6.33 & 4.4630 & 1.018 & 1.036 & .079 & .354 & -1.057 & .695 \\
\hline
\end{tabular}

Table 3.

Victim profile

\begin{tabular}{|c|c|c|c|c|c|c|c|}
\hline & $\mathrm{N}$ Min & Max & $\mathrm{M}$ & SD & Variance & Skewness & tosis \\
\hline Aggression Proactive & 541 & 2 & 1.22 & .287 & .082 & 2.096 .3274 .312 & .644 \\
\hline Aggression Reactive & 541 & 2 & 1.71 & .379 & .144 & $\begin{array}{lll}.464 & .327 & -.318\end{array}$ & .644 \\
\hline Aggression Bullying & 541 & 2 & 1.35 & .223 & .050 & $.621 \quad 3251.036$ & .639 \\
\hline Victimization Bullying & 541 & 5 & 2.26 & .637 & .406 & 1.713 .3255 .095 & .639 \\
\hline Self-esteem & 541 & 3 & 2.40 & .345 & .119 & -.975 .3252 .334 & .639 \\
\hline Extraversion & $54 \quad 1$ & 5 & 3.32 & .942 & .888 & $-.169 .325-.291$ & .639 \\
\hline Agreeableness & 542 & 5 & 3.60 & .773 & .598 & $-.132 .325-.394$ & .639 \\
\hline Conscientiousness & $54 \quad 1$ & 5 & 3.41 & .901 & .812 & $\begin{array}{lll}-.716 & .325 & .532\end{array}$ & .639 \\
\hline Neuroticism & 541 & 5 & 3.04 & .966 & .933 & $.201 \quad .325-.679$ & .639 \\
\hline Openness & 541 & 5 & 3.94 & .917 & .840 & $\begin{array}{llll}-.660 & .325 & .313\end{array}$ & .639 \\
\hline Social values & 541.89 & 7 & 4.60 & 1.241 & 1.542 & $\begin{array}{lll}-.040 & .325 & -.383\end{array}$ & .639 \\
\hline Personal values & 542.33 & 7 & 5.23 & 1.237 & 1.532 & $-.791 .325-.113$ & .639 \\
\hline Individual values & 542.00 & 6.83 & 4.17 & 1.357 & 1.843 & $\begin{array}{llll}.230 & .327 & -.906 \\
\end{array}$ & .644 \\
\hline
\end{tabular}


12 Jara, Casas \& Ortega-Ruiz-Aggressive Behaviour

Table 4.

Bully-victim profile

\begin{tabular}{|c|c|c|c|c|c|c|c|c|}
\hline & $\mathrm{N}$ & Min & $\operatorname{Max}$ & $\mathrm{M}$ & SD & Variance & Skewness & Kurtosis \\
\hline Aggression Proactive & 12 & 1 & 3 & 1.47 & .444 & .198 & 1.560 .637 & 1.232 \\
\hline $\begin{array}{l}\text { ggression } \\
\text { Reactive }\end{array}$ & 12 & 1 & 3 & 1.93 & .349 & .122 & 1.019 .637 & 132 \\
\hline $\begin{array}{l}\text { ggression } \\
\text { ullying }\end{array}$ & 12 & 1 & 5 & 2.90 & 1.211 & 1.467 & .354 .637 & -1.04 \\
\hline Victimization Bullying & 12 & 1 & 2 & 1.27 & .276 & .076 & 1.144 .637 & .6631 .232 \\
\hline elf- & 12 & 2 & 3 & 2.36 & .248 & .062 & .482 .637 & 1.6 \\
\hline$x \operatorname{tr}$ & 12 & 3 & 5 & 4.38 & .678 & .460 & -.770 .637 & -.3261 .232 \\
\hline gre & 12 & 2 & 4 & 3.08 & .597 & .356 & .007 .637 & -.2031 .232 \\
\hline ons & 12 & 1 & 5 & 2.54 & 1.270 & 1.612 & .608 .637 & -.4331 .232 \\
\hline Neurc & 12 & 1 & 5 & 2.88 & 1.316 & 1.733 & -.034 .637 & $-.981 \quad 1.232$ \\
\hline Inen & 12 & 3 & 5 & 3.96 & .722 & .521 & .389 .637 & -.9251 .232 \\
\hline oci & 121 & 1.89 & & 3.86 & 1.346 & 1.812 & -.075 .637 & $.073 \quad 1.232$ \\
\hline 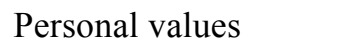 & 121 & & & 4.64 & 1.633 & 2.669 & -1.054 .637 & -.3931 .232 \\
\hline Individual values & 122 & & & 4.63 & 1.195 & 1.428 & -.247 .637 & -1.1811 .232 \\
\hline
\end{tabular}

With regard to the second research objective, we performed four structural equation models (see Figures 1, 2, 3 and 4) to analyze the influence of the variables that capture personality, self-esteem and values with respect to the two major dimensions considered in the study, proactive and reactive aggression. To this end, we considered the division between involvement and non-involvement in bullying as previously explained. The calculated models are composed of nine types of observable variables (extraversion, agreeableness, conscientiousness, neuroticism, openness to experience, self-esteem, personal values, social values and individual values) and factors of proactive and reactive aggression.

Those scoring 2 or less on the victimization items and 3 or more on the aggression items were considered aggressors, while those scoring 2 or more on both the bullying and the aggression scale were considered both aggressors and victims of other aggressors (bully-victims). Those classified as victims scored 2 or less on the aggression items of the bullying scale and 
3 or more on the victimization items. The results of the analyses reveal that a significant number of subjects are involved in three distinct bullying roles. Moreover, the aggressors outnumber the victims in both types of aggression studied, while the bully-victims show the highest mean scores in terms of both aggressive behavior and bullying.

The first model calculated with those not involved in bullying using proactive aggression as the dependent variable shows an acceptable fit in line with $\mathrm{Hu}$ and Bentler (1999). The multivariate normality coefficient shows a value of 215.66. The following results were obtained for the goodness-of-fit indices: $\chi^{2}=2844.59 ; \mathrm{DF}=1076 ; \chi 2 / \mathrm{df}=2.64 ; p=.000$; $\mathrm{CFI}=.96 ; \mathrm{NNFI}=.95 ; \mathrm{IFI}=.962$ and $\mathrm{RMSEA}=.062$, thus predicting $36 \%$ of the variance of the dependent variable.

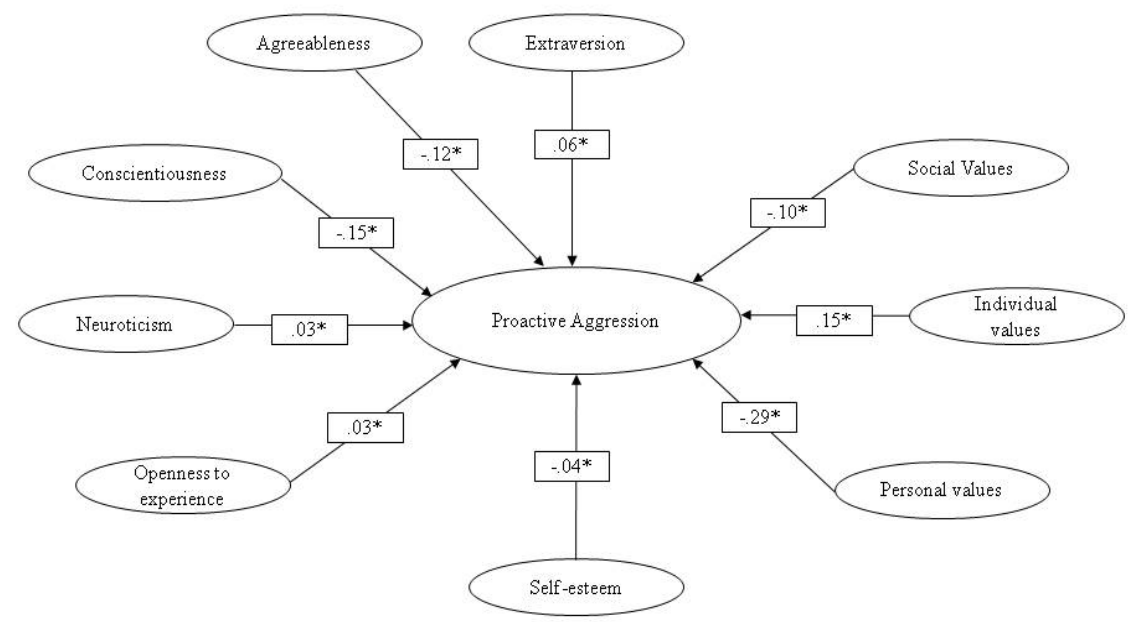

Figure 1. Structural equation model for proactive aggression (non-involvement) using personality, values and self-esteem variables. 


\section{Jara, Casas \& Ortega-Ruiz-Aggressive Behaviour}

The second model was calculated with those involved in bullying using proactive aggression as a dependent variable. As above, the model shows an acceptable fit. The multivariate normality coefficient shows a value of 96.37 . The results of the goodness-of-fit indices were as follows: $\chi 2=2853.52$; $\mathrm{DF}=1128 ; \chi 2 / \mathrm{df}=2.52 ; p=.000 ; \mathrm{CFI}=.92 ; \mathrm{NNFI}=.93 ; \mathrm{IFI}=.929$ and RMSEA $=.062$, thus predicting $30.3 \%$ of the variance of the dependent variable.

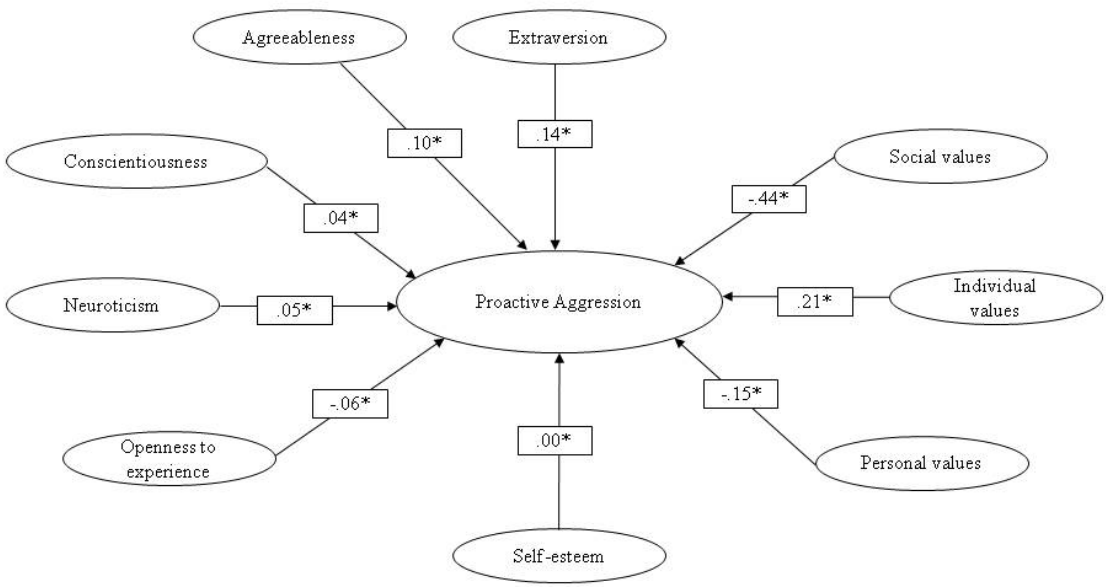

Figure 2. Structural equation model for proactive aggression (involvement) using personality, values, and self-esteem variables.

The third model was calculated with those not involved in bullying using reactive aggression as a dependent variable and shows an acceptable fit, subject to the same considerations. The multivariate normality coefficient shows a value of 1169.30 . And the adjustment indices yield the following results $\chi^{2}=3254.57 ; \mathrm{DF}=1171 ; \chi^{2} / \mathrm{df}=2.77 ; p=.000 ; \mathrm{CFI}=.98 ; \mathrm{NNFI}=$ 
.96 ; IFI $=.986$ and RMSEA $=.064$, thus predicting $33 \%$ of the variance of the dependent variable.

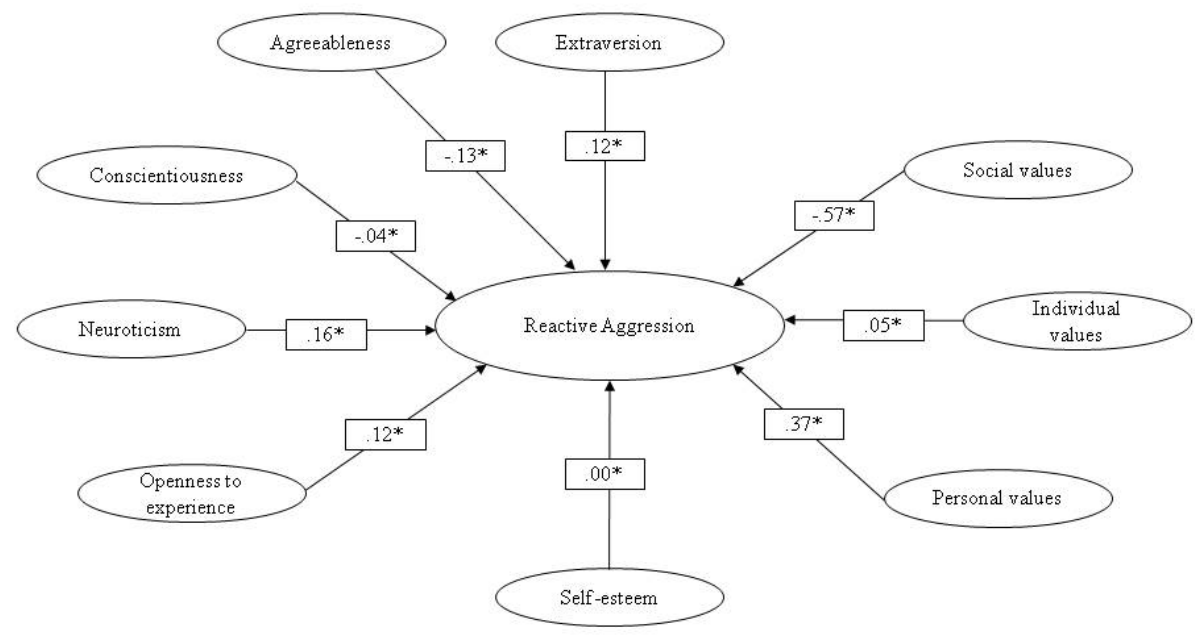

Figure 3. Structural equation model for reactive aggression (non-involvement) using personality, values, and self-esteem variables.

The fourth model was calculated with those involved in bullying using reactive aggression as the dependent variable. As above, the model shows an acceptable fit. The multivariate normality coefficient shows a value of 56.43 . The goodness-of-fit indices yielded the following results: $\chi 2=2132.32$; $\mathrm{DF}=1171 ; \chi 2 / \mathrm{df}=1.82 ; p=.000 ; \mathrm{CFI}=.92 ; \mathrm{NNFI}=.93 ; \mathrm{IFI}=.929$ and $\operatorname{RMSEA}=.074$, thus predicting $54 \%$ of the variance of the dependent variable. 


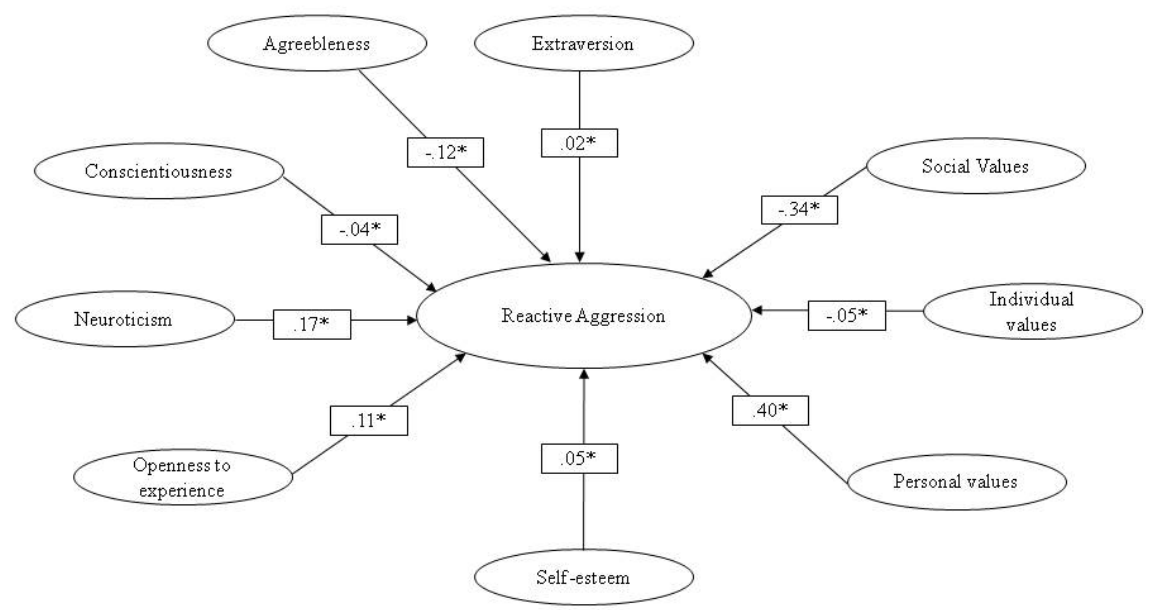

Figure 4. Structural equation model for reactive aggression (involvement) using personality, values, and self-esteem variables.

Regarding the relationships between the variables and the different types of aggression (see figures 1, 2, 3 and 4), the standardized regression coefficients show that the nine variables exert a direct effect on all four models. According to the predictive power of the variables in the models, it is important to highlight the following. In the second model (proactive aggression with bullying involvement), social values show a negative relationship with aggression $(\beta=-.44 ; p<.05)$ in contrast to individual values, which show a direct and significant relationship with aggression $(\beta=.21 ; p<.05)$. In the first model (proactive aggression with no bullying involvement), personal values are negatively related to proactive aggression $(\beta=.29 ; p<.05)$, while individual values have a direct and positive relationship with aggression $(\beta=.15 ; p<.05)$. As regards the fourth model (reactive aggression with bullying involvement), social values have an inverse relationship with reactive aggression $(\beta=.57 ; p<.05)$, while personal values have a direct and positive relationship $(\beta=.37 ; p<.05)$. As regards the third model (reactive aggression with no bullying involvement), social values have an inverse relationship $(\beta=.34 ; p<.05)$ and personal 
values have a positive relationship with reactive aggression $(\beta=.40$; $p<.05)$.

\section{Discussion and Conclusions}

The first objective of this study was to determine the level of involvement in bullying in a sample of adolescents, the percentages of aggressors, victims and bully-victims in the sample and the proactive and the reactive aggressive behavior patterns that are involved. The results reveal that a considerable number of participants were involved in bullying. In line with the literature review, personality is a factor to be considered in individual aggressiveness as it influences the level of involvement in violence in schools and hence in bullying (Massa, 2004). From a cognitive perspective, aggressors involved in bullying display a more complex personality, as do bully-victims. Victims do not exhibit a defined pattern of behavior but their personal traits are different from those of bully-victims and aggressors. These conclusions coincide with other studies showing that aggressors and victims have different personality traits (Ortega, 2010). The results of this study support several other studies which demonstrate that both proactive and reactive aggression is linked to the most basic traits of personality types.

The relationship between the personality variable and proactive aggression highlights that the participants not involved in bullying are more ethically conscientious and socially more agreeable. Taking into account these two variables and the subjects involved in proactive aggression, we found a difference in ethical conscientiousness: for those not involved in bullying ethical conscientiousness is a protective factor, while for those involved in bullying it is a risk factor. This result is significant and provides further evidence to support the widely studied personality of the aggressor in terms of what differentiates those involved in bullying from those who are not. The difference has to do with aspects of personality related to moral criteria, confirming to what extent bullying is a problem of immorality in unjustified aggressive behavior, as argued by Ortega (2010).

Regarding the relationship between personality and reactive aggression, the results for those not involved in bullying are significant given that neuroticism is a very significant risk factor. In other words, the reactive 


\section{Jara, Casas \& Ortega-Ruiz-Aggressive Behaviour}

aggressive behavior pattern is closely associated with displaying certain neurotic personality traits. Extraversion is also a variable that strongly influences involvement or non-involvement in this type of aggression, as is openness to experience or an open mentality. Those involved in bullying showed a higher score on the reactive aggression scale for neuroticism and openness to experience. This finding is of major significance given that differences were also found between proactive and reactive aggression in terms of personality. Specifically, for those involved in proactive aggression, agreeableness is a protective factor, while for those involved in reactive aggression it is a significant risk factor (Pailing et al., 2014; Rammstedt \& John, 2007).

These values bring to light very important results taking into account the three profiles of involvement in bullying (aggressors, bully-victims and victims) and enable reaching meaningful conclusions in this line of research. Social values are more important for aggressors, and although this level of importance does not differ much from that of victims, it does differ from bully-victims who score less on the scale. In other words, on the whole, aggressors involved in bullying attach more importance to society and this is highlighted both in their personal characteristics and the importance they give to social values. Personal values are important for both aggressors and victims, but are less important for bully-victims. This may suggest that the greater the involvement in bullying, the less importance is given to personal values in general. Finally, individual values showed higher scores for aggressors, lower scores for victims and the lowest scores for bully-victims. These differences between the three profiles regarding the importance of personal and social values are supported by the findings of Erikson and Schwartz, who argue that moral criteria differ according to the level of involvement in aggressive acts (Erikson, 1968; Schwartz \& Boehnke, 2004).

As regards the second objective, to determine the impact of the variables personality, values and self-esteem, this study has shown that the variables support the initial hypothesis. A significant relationship was found between the variables of personality, self-esteem and values and the two aggressive behavior patterns in relation to involvement and non-involvement in bullying and are therefore in consonance with the ideas of Salmivalli and Nieminen (2002). 
The personality variables remained more or less stable in victims and aggressors. When compared, it can be seen that extraversion is greater in aggressors, as opposed to ethical conscientiousness, which appears to be more latent in victims. In bully-victims who do not exhibit a homogeneous personality pattern, something which is more akin to the personality of victims, ethical conscientiousness is not stable. In relation to self-esteem, the aggressors show the highest rates. This is based on the previous hypothesis that there are contradictory aspects with respect to self-esteem, especially in the case of aggressors (Marsh et al., 2001; McCarthy \& Hoge, 1984). Indeed, in terms of self-esteem there are no major differences between the patterns of proactive and reactive aggression, which leads us to believe that determinant variables other than self-esteem are involved in differentiating proactive and reactive patterns of aggressive behavior. In other words, perhaps this result indicates, as many studies argue, that although selfesteem is an important factor to consider, there may be other personal variables and ethical components of personality that override this selfevaluative factor. It may also indicate a weakness of the study, such as the small sample size and small number of subjects involved in aggressive behavior of one type or another, which does not allow for a more precise approximation of the role that self-esteem plays in discriminating the greater or lesser impact of being or not being a bullying aggressor.

Especially relevant in this study is that the results of the models predict aggression in relation to the variables, both for personality and the specific assessment tool used to measure social and moral values. Specifically, this study shows that there is a relationship between involvement and noninvolvement in bullying and individual, personal and social values. The results for those involved in bullying highlight that social values are a determining factor in proactive aggression. In other words, social values significantly decrease the likelihood of proactive aggression. In statistical terms, the results indicate that personal values have a positive impact on proactive aggression. When personal values obtain a higher score, aggression increases, thus suggesting that higher scores in personal values and lower ones in social values - lead to a greater likelihood of aggression. Something quite similar can be observed in terms of those involved in 


\section{Jara, Casas \& Ortega-Ruiz-Aggressive Behaviour}

reactive aggression; it seems that individual ethics versus more social ethics is determinant in terms of both proactive and reactive aggressive behavior.

Those not involved in bullying also present interesting results regarding personal and social values. The results indicate that social values cause proactive aggression to decrease, in other words, they act as a protective factor. In contract, a high individual values score has a totally opposite effect, in other words, a personal and perhaps egocentric vision acts as a risk factor. Conversely, for those not involved in bullying, the results clearly shown that social values and personal values also have a decisive impact on reactive aggression. Specifically, the former decrease and the latter increase the likelihood of reactive aggression. Taking into account these results and in relation to the above research, it seems evident that values are determinant variables whose presence modulates patterns of proactive and reactive aggressive behavior in those involved and not involved in bullying (Erikson, 1968; Hofstede, 1980; Oliva, 2011; Triandis, Bontempo, Villareal, Asai, \& Lucca, 1988).

We can confirm that the findings of this study corroborate the fact that the variables relating to personal and social values are also related to proactive and reactive aggression in bullying, both for involvement and noninvolvement, regardless of the way adolescents become involved: either as aggressors with a greater tendency to exhibit proactive aggression or as victims with a greater tendency for reactive aggressive behavior.

Given the significant role we must attribute to moral (personal) and ethical (social) values and to the differential nuances of both highlighted in the assessment tools used, the ethical dimension in its two facets - the more personal and perhaps individualistic facet and the more social facet that may be more closely related to moral criteria - must be studied in greater depth with better assessment tools. However, these limitations do not veil the scope of this study on aggressive behavior in bullying when adopting a perspective that differentiates its two major patterns: proactive and reactive aggressive behavior. 


\section{References}

Bandura, A. (1973). Aggression: A social learning analysis. Prentice-Hall. Retrieved from http://psycnet.apa.org/psycinfo/1974-00914-000

Bandura, A. (1999). Social cognitive theory of personality. Handbook of Personality: Theory and Research, 154-196.

Caprara, G. V., \& Pastorelli, C. (1993). Early emotional instability, prosocial behaviour, and aggression: Some methodological aspects. European Journal of Personality, 7(1), 19-36.

Cerezo, F. (2002). El bullying y su relación con las actitudes de socialización en una muestra de adolescentes. Revista Electrónica Interuniversitaria de Formación Del Profesorado, 5(1), 10-16.

Crick, N. R., \& Dodge, K. A. (1996). Social information-processing mechanisms in reactive and proactive aggression. Child Development, 67(3), 993-1002.

Del Barrio, C., Martín, E., Almeida, A., \& Barrios, Á. (2003). Del maltrato y otros conceptos relacionados con la agresión entre escolares, y su estudio psicológico. Infancia Y Aprendizaje, 26(1), 9-24.

Dodge, K. A., \& Coie, J. D. (1987). Social-information-processing factors in reactive and proactive aggression in children's peer groups. Journal of Personality and Social Psychology, 53(6), 1146.

Dodge, K. A., \& Schwartz, D. (1997). Social information processing mechanisms in aggressive behavior. Retrieved from http://psycnet.apa.org/psycinfo/1997-36421-017

Erikson, E. H. (1968). Youth and crisis. WW Norton\&Company, New YorkLondon, 17.

Flora, D. B., \& Curran, P. J. (2004). An empirical evaluation of alternative methods of estimation for confirmatory factor analysis with ordinal data. Psychological Methods, 9(4), 466. doi:10.1037/1082989X.9.4.466

Hart, D., Hofmann, V., Edelstein, W., \& Keller, M. (1997). The relation of childhood personality types to adolescent behavior and development: A longitudinal study of Icelandic children. Developmental Psychology, 33(2), 195. 


\section{Jara, Casas \& Ortega-Ruiz-Aggressive Behaviour}

Hofstede, G. (1980). Angola coffee-Or the confrontation of an organization with changing values in its environment. Organization Studies, 1(1), 21-40.

Hu, L., \& Bentler, P. M. (1999). Cutoff criteria for fit indexes in covariance structure analysis: Conventional criteria versus new alternatives. Structural Equation Modeling: A Multidisciplinary Journal, 6(1), 155.

Marsh, H. W., Parada, R. H., Yeung, A. S., \& Healey, J. (2001). Aggressive school troublemakers and victims: a longitudinal model examining the pivotal role of self-concept. Journal of Educational Psychology, 93(2), 411.

Massa, J. L. P. (2004). Introducción: Agresión y comportamiento en la adolescencia. Monografias de Psiquiatría, 16(1), 1-20.

McCarthy, J. D., \& Hoge, D. R. (1984). The dynamics of self-esteem and delinquency. American Journal of Sociology, 396-410.

Monks, C., \& Ruiz, R. O. (2005). Agresividad injustificada entre preescolares. Psicothema, 17(3), 453-458.

Oliva, A. (2011). Desarrollo positivo adolescente y los activos que lo promueven: un estudio en centros docentes andaluces. Junta de Andalucía, Secretaría General de Salud Pública y Participación.

Olweus, D. (1993). Bullying at school: what we know and what we can do. Oxford, UK; Cambridge, USA: Blackwell.

Ortega, R. (2010). Agresividad injustificada, bullying y violencia escolar. Madrid: Alianza Editorial.

Ortega, R., \& Mora-Merchán, J. A. (2008). Las redes de iguales y el fenómeno del acoso escolar: explorando el esquema dominiosumisión. Infancia Y Aprendizaje, 31(4), 515-528. doi: 10.1174/021037008786140922

Ortega-Ruiz, R., Del Rey, R., \& Casas, J. A. (2016). Evaluar el bullying y el cyberbullying validación española del EBIP-Q y del ECIP-Q. Psicología Educativa, 22(1), 71-79. doi:10.1016/j.pse.2016.01.004

Ortega-Ruiz, R., Sánchez, V., \& Menesini, E. (2002). Violencia entre iguales y desconexión moral: un análisis transcultural. Psicothema, 14(1), 37-49. 
Pailing, A., Boon, J., \& Egan, V. (2014). Personality, the Dark Triad and violence. Personality and Individual Differences, 67, 81-86. doi:10.1016/j.paid.2013.11.018

Pellegrini, A. D., Bartini, M., \& Brooks, F. (1999). School bullies, victims, and aggressive victims: factors relating to group affiliation and victimization in early adolescence. Journal of Educational Psychology, 91(2), 216.

Poulin, F., \& Boivin, M. (1999). Proactive and reactive aggression and boys' friendship quality in mainstream classrooms. Journal of Emotional and Behavioral Disorders, 7(3), 168-177.

Poulin, F., \& Boivin, M. (2000). Reactive and proactive aggression: Evidence of a two-factor model. Psychological Assessment, 12(2), 115-122. http://doi.org/10.1037/1040-3590.12.2.115

Pullmann, H., \& Allik, J. (2000). The Rosenberg Self-Esteem Scale: its dimensionality, stability and personality correlates in Estonian. Personality and Individual Differences, 28(4), 701-715. https://doi.org/10.1016/S0191-8869(99)00132-4

Raine, A., Dodge, K., Loeber, R., Gatzke-Kopp, L., Lynam, D., Reynolds, C., ... Liu, J. (2006). The reactive-proactive aggression questionnaire: differential correlates of reactive and proactive aggression in adolescent boys. Aggressive Behavior, 32(2), 159-171. doi:10.1002/ab.20115

Rammstedt, B., \& John, O. P. (2007). Measuring personality in one minute or less: A 10-item short version of the Big Five Inventory in English and German. Journal of Research in Personality, 41(1), 203-212. doi:10.1016/j.jrp.2006.02.001

Rutter, M., Giller, H., \& Hagell, A. (2000). La conducta antisocial de los jóvenes. Retrieved from http://dialnet.unirioja.es/servlet/libro?codigo $=228964$

Salmivalli, C., \& Nieminen, E. (2002). Proactive and reactive aggression among school bullies, victims, and bully-victims. Aggressive Behavior, 28(1), 30-44. doi:10.1002/ab.90004

Samper, P., Tur, A. M., Mestre, V., \& Cortés, M. T. (2008). Agresividad y afrontamiento en la adolescencia. Una perspectiva intercultural. 
24 Jara, Casas \& Ortega-Ruiz-Aggressive Behaviour

International Journal of Psychology and Psychological Therapy, 8(3), 431-440.

Schwartz, S. H., \& Boehnke, K. (2004). Evaluating the structure of human values with confirmatory factor analysis. Journal of Research in Personality, 38(3), 230-255. doi:10.1016/S0092-6566(03)00069-2

Stoudt, B. G. (2006). "You're Either In or You're Out" School Violence, Peer Discipline, and the (Re) Production of Hegemonic Masculinity. Men and Masculinities, 8(3), 273-287. doi:10.1177/1097184X05282070

Triandis, H. C., Bontempo, R., Villareal, M. J., Asai, M., \& Lucca, N. (1988). Individualism and collectivism: Cross-cultural perspectives on self-ingroup relationships. Journal of Personality and Social Psychology, 54(2), 323.

Xu, Y., Raine, A., Yu, L., \& Krieg, A. (2014). Resting heart rate, vagal tone, and reactive and proactive aggression in Chinese children. Journal of Abnormal Child Psychology, 42(3), 501-514. doi:10.1007/s10802013-9792-2

Zych, I., Ortega-Ruiz, R., \& Del Rey, R. (2015). Scientific research on bullying and cyberbullying: Where have we been and where are we going. Aggression and Violent Behavior, 24, 188-198. doi:10.1016/j.avb.2015.05.015

Natalia Jara is PhD student in the department of psychology at the University of Cordoba

Jose Antonio Casas is Assistant professor of the Department of Psychology of the University of Cordoba

Rosario Ortega-Ruiz is Full Professor of the Department of Psychology at the University of Cordoba

Contact Address: Avda. San Alberto Magno S/N 14004 Cordoba (Spain) 